\title{
ATRX Gene
}

National Cancer Institute

\section{Source}

National Cancer Institute. ATRX Gene. NCI Thesaurus. Code C74976.

This gene plays a role in the regulation of both chromatin remodeling and transcription. 